\title{
DENUNCIAS
}

ESTUPRO CONTRA A MULI INDÍGENA: BIOÉT INTERCULTURAL FEMINI SAÚDE COLETIVA E JUST 


\section{DENUNCIAS DE ESTUPRO CONTRA A MULHER INDÍGENA: BIOÉTICA INTERCULTURAL FEMINISTA, SAÚDE COLETIVA E JUSTIÇA}




\title{
DENUNCIAS DE ESTUPRO CONTRA A MULHER INDÍGENA: BIOÉTICA INTERCULTURAL FEMINISTA, SAÚDE COLETIVA E JUSTIÇA
}

\section{Resumo}

A resolução da violência pelo Estado reafirma o imaginário colonizador de que os povos indígenas não têm lei e nem ética, e se exige criminalização e pena de prisão para os indígenas. A pesquisa sobre violência sexual em Terras Indígenas no Vale do Guaporé, fronteira com a Bolívia, ocorreu através de análise de Inquéritos Policiais de denuncias de estupro, entrevistas e etnografia. Confirma o despreparo do Estado para a convivência plural e os limites biomédicos para questões de saúde coletiva. Através do conceito de interculturalidade se propõe uma Bioética Intercultural Crítica e Feminista que engloba idéias sobre o bem-estar e justiça.

Palavras-chave: Estupro, mulher indígena, Bioética.

\section{REPORTS OF RAPE AGAINST INDIGENOUS WOMEN: FEMI- NIST INTERCULTURAL BIOETHICS, COLLECTIVE HEALTH AND JUSTICE}

\begin{abstract}
The resolution of violence by the State reaffirms the colonizing imaginary that indigenous peoples have neither law nor ethics, and requires criminalization and imprisonment for the Indians. The research on sexual violence in Indigenous Lands in the Guaporé Valley, bordering Bolivia, occurred through analysis of Police Inquiries of reports of rape, interviews and ethnography. It confirms the unpreparedness of the State for plural coexistence and the biomedical limits for collective health issues. Through the concept of interculturality, a Critical and Feminist Intercultural Bioethics is proposed encompassing ideas on well-being and justice.
\end{abstract}

Keywords: Rape, indigenous woman, bioethics. 


\section{DENUNCIAS DE VIOLACIÓN CONTRA LA MUJER INDÍGENA: BIOETICA INTERCULTURAL FEMINISTA, SALUD COLECTIVA Y JUSTICIA}

\section{Resumen}

La resolución de la violencia por parte del Estado reafirma el imaginario colonizador de que los indígenas no tienen ni ley ni ética, y exige la criminalización y el encarcelamiento de los indios. La investigación sobre violencia sexual en las tierras indígenas del Valle del Guaporé, en la frontera con Bolivia, se realizó mediante análisis de reportes policiales de denuncia de violación, entrevistas y etnografía. Se confirma la inoperancia del Estado para la convivencia plural y los límites biomédicos para los problemas de salud pública. A través del concepto de interculturalidad, se propone una Bioética Intercultural Crítica y Feminista que abarque ideas sobre el bienestar y la justicia.

Palabras clave: Violación, Mujer indígena, Bioética.

Endereço do autor para correspondência: Rua Ana Loiola de Alencar, 813. Bairro: Pimenta Crato- CE. CEP.: 63.113-424.

cemin@unir.br 


\section{INTRODUÇÃO}

Diferentes tipos de violências intra e interétnicas vêm requerendo e mobilizando a atenção das comunidades afetadas. Entre as violências, os casos de estupro são de difícil abordagem em vista do nosso desconhecimento das culturas envolvidas. A violência intraétnica e a criminalização de indígenas é tema pouco estudado no Brasil, segundo Silva (2009), que revisou a literatura sobre a criminalização e a situação penal de índios no país. O autor distingue os processos sociais geradores das ações de crime, dos processos judiciais que podem resultar em encarceramento. A primeira questão ele remete à criminologia, e a segunda à operacionalidade da justiça.

Além dos dois aspectos citados por Silva, destaco neste artigo a dimensão cultural, tanto dos processos sociais geradores de crime quanto dos processos judiciais, por considerar que a mesma cultura etnocêntrica constitui os dois fenômenos. Apresento, neste artigo, dados para argumentar que a complexidade do fenômeno da violência requer pesquisa empírica e formulação teórica, em um campo aqui denominado de Bioética Intercultural Crítica e Feminista como início daquilo que deverá ser um longo percurso de estudo. Neste artigo, o foco são os dados relativos às acusações de estupro.

O artigo está dividido em três partes, além da introdução e da conclusão. A primeira apresenta a metodologia, a segunda comunica a ideia de uma Bioética Intercultural Crítica e Feminista, e a terceira, interpreta os resultados da pesquisa.

Depois da conclusão, um tópico expõe os dados empíricos dos Inquéritos, das entrevistas e da etnografia, apresentando as cenas, os cenários e os personagens. Cada acusação de estupro é apresentada separadamente, como "cenas", que aparecem numeradas de 1 a 8 . As cenas convidam a olhar, pois permitem visão panorâmica e, ao mesmo tempo, singularizada das diferentes situações denunciadas como estupro. Optou-se por apresentá-las ao final, para não sobrecarregar o texto. Assim, embora fundamental, a leitura dos dados empíricos pode ser feita independente do corpo principal do texto. O objetivo geral do artigo, portanto, é expor resultados de pesquisa e anunciar um programa de pesquisa que se encontra em desenvolvimento.

\section{A PESQUISA}

Os dados do artigo decorrem de dois projetos de pesquisa, um em 2008, "O Alcoolismo, a violência de gênero, os transtornos mentais, o suicídio e o homicídio no DSEI Porto Velho" foi financiado pelo Ministério da Saúde (110217111517) e, coordenado por Ari Miguel Teixeira Ott, (Cemin \& Ott 2009). O outro projeto foi financiado pelo CNPq (402967/2008-9), em 2010 (Cemin 2011a). Os dois projetos foram aprovados pelo Comitê de Ética em Pesquisa da Universidade Federal de Rondônia. O primeiro possibilitou entrevistar homens e mulheres indígenas na CASAI (Casa de Saúde do Índio) e no Porto da FUNAI em 
Guajará Mirim. Também realizei entrevistas em duas Terras Indígenas (TI), a TI Pakaas Novas, uma das áreas Wari, e a TI Guaporé, esta última habitada por vários povos. Ambas as TIs fazem fronteira com a Bolívia, e comerciantes bolivianos, chamados "marreteiros", são acusados de vender bebidas alcoólicas nas aldeias. As entrevistas, tanto nas TIs visitadas quanto em Guajará Mirim, evidenciaram unanimidade quanto à ocorrência comum de mulheres serem agredidas fisicamente, resultando em sequelas que elas reportam como graves. A cidade de Guajará Mirim está separada da Bolívia apenas pelo Rio Mamoré, com trafego intenso e cotidiano entre as duas nacionalidades. Guajará Mirim tem população estimada em 39.853 residentes dos quais cerca de $7,1 \%$ são indígenas. As TIs do município contam com 4.245 habitantes, sendo que mais de $90 \%$ são da etnia Wari. Os Wari, linguisticamente classificados como Txapakura, se dividem em vários subgrupos: Oro Nao, Oro At; Oro Bone; Oro Rame; Oro Rame Xijeim; Oro Eo; Oro Win; Oro Join; distribuídos em quatro Terras Indígenas: 1. Igarapé Ribeirão; 2. Igarapé Laje; 3. Pakaá- Nova (fronteira com a Bolívia); Sagarana (fronteira com a Bolívia) e, 5. Rio Negro Ocaia. As terras estão mais ou menos localizadas nos territórios tradicionais dos subgrupos, embora em todos eles se possam encontrar pessoas de outras etnias, em função de casamentos ou motivações diversas (Maldi 1983, Vilaça 1992).

O Projeto de 2010, "Violências que afetam as mulheres indígenas: tipos, contextos e estratégias de proteção dentro do respeito à pauta do direito à diferença" foi coordenada por Rita Laura Segato. A pesquisa foi configurada em rede, e composta por quatro subprojetos. No caso da pesquisa de 2008 e do subprojeto aqui abordado, trata-se daquilo que Segato (2011) chama de "Antropologia por demanda": uma prática de pesquisa antropológica solicitada por indivíduos e grupos vulnerabilizados e que por isso constitui desafio teórico e metodológico. Em Rondônia, lideranças indígenas são tomadas de perplexidade a cada vez que ocorrem denúncias de violência que os envolve. Nessas ocasiões recorrem à Universidade e aos antropólogos (as), de maneira individualizada, em busca de conhecimento que possa nortear as suas ações, configurando assim, a Antropologia por demanda.

O subprojeto que informa este artigo tinha como objetivo identificar e descrever processos de Inquérito Policial motivados por violência entre homens e mulheres indígenas, na Delegacia da Mulher e na Polícia Federal do município de Guajará Mirim (RO), relativos aos anos de 2003 a 2010. Os levantamentos de Inquéritos Policiais mostraram diversas modalidades de violências: agressões físicas, estupros e assassinatos de mulheres. $\mathrm{O}$ acesso aos dados se deu através de autorizações. O procedimento foi verificar as pastas de processo e separar aquelas nas quais constavam sobrenomes indígenas. Os nomes aqui apresentados são fictícios e foi suprimida a referência aos clãs, visando dificultar, ainda mais a identificação das pessoas. A nominação étnica mantida pelos indígenas evita, em 
grande parte, a descaracterização que o uso da categoria "pardo" produz, pois é nessa categoria que eles costumam ser classificados nos registros oficiais (Cenas 4 e 5). Este fato de descaracterização, também foi assinalado por Silva (2013).

Foram entrevistadas 19 mulheres na cidade de Guajará Mirim e na Aldeia Ricardo Franco, todas relataram sucessivos casos de espancamento praticados contra ela por seus maridos. Estupros foram categorizados como sendo prática comum e quatro deles foram narrados. Dois referidos como muito graves, foram relatados por Maria (por segurança a etnia não será mencionada) em sigilo e com temor, pois um dos casos envolve o filho de liderança indígena e, pai e filho, residem na mesma aldeia que ela. No segundo caso, a vítima teria ido a óbito, em decorrência da agressividade do estupro. $\mathrm{O}$ terceiro caso é público, pois o marido de Marcela encontrava-se aprisionado em cadeia pública, em Guajará Mirim, acusado de ter estuprado uma ex-namorada. O quarto caso foi referido também por Marcela que informou que a vítima deste caso quase foi a óbito.

\section{DA BIOÉTICA DE INTERVENÇÃO À BIOÉTICA INTERCULTURAL FEMI- NISTA}

O exercício da "Antropologia por demanda" me levou ao Pós-Doutorado em Bioética na Universidade de Brasília, UNB, na área de concentração "Problemas Persistentes em Saúde Pública", na linha de Pluralismo Histórico e Bioético, onde se inclui também o Pluralismo Jurídico. O estágio foi supervisionado por Rita Laura Segato. Um dos resultados desse estágio foi a aprovação pelo CNPq (Processo ${ }^{\circ}$ 405211/2012-0 - APQ), em dezembro de 2012, de um projeto sob a minha coordenação, intitulado "Violências contra as Mulheres Indígenas e a Lei Maria da Penha, na perspectiva de uma Bioética Intercultural Crítica e Feminista". A equipe do projeto foi composta por pesquisadores e pesquisadoras da UNB, de diferentes áreas: Antropologia, Direito, Bioética e Saúde Coletiva. O projeto, embora aprovado no Comitê de Ética da Universidade Federal de Rondônia, não obteve parecer do CONEP, quer favorável ou desfavorável, o que inviabilizou a continuidade da pesquisa de campo. Assim, não apresento dados na perspectiva indígena sobre a ideia de Bioética intercultural.

Entretanto, a proposta em si, motivada pelas pesquisas anteriores, e apresentada em diversos eventos de Bioética, contribuiu para recolocar o tema da violência contra a mulher indígena articulada ao Feminismo, a Bioética, a Interculturalidade e aos Direitos; somando-se a outros esforços no mesmo sentido, a exemplo da tese de Fonseca (2016) e da dissertação de Sales (2016) orientada por Lorenzo, que, anteriormente, argumentou por uma Bioética Clínica Interétnica (Lorenzo 2011) para dar conta da falta de preparo dos profissionais de saúde no atendimento à saúde indígena diferenciada. E ainda, Albuquerque (2015), Vitoy (2015).

Na UNB destaca-se a Bioética de Intervenção proposta por Garrafa e em desenvolvimento por colaboradores 
(Garrafa \& Porto 2003, Nascimento \& Garrafa 2011, Nascimento \& Feitosa 2015, Feitosa 2015). A Bioética de Intervenção defende a Saúde Pública através de intervenção teórica e política nos problemas persistentes que agravam as condições de vida da população brasileira. Consoante com as Bioéticas Latino-americanas considera a especificidade dos países do Sul, frente ao Norte, e a defesa e ampliação dos Direitos Humanos (UNESCO). O paradigma Latino-Americano em Bioética influenciou e reciprocamente se legitimou politicamente com a Declaração Universal de Bioética e Direitos Humanos da UNESCO (2005). A Bioética Latino-Americana ainda se diversifica no Brasil em Bioética da Libertação, de Proteção, Feminista e Antirracista, entre outras denominações. A Bioética Intercultural Crítica e Feminista que desenvolvo se beneficia das Bioéticas Latino-Americanas, mas é o início da minha resposta para os desafios da Antropologia por demanda acima referida.

Roberto Cardoso de Oliveira (1994) escreveu sobre a necessidade de uma "etnoética", visando dar conta das relações entre o Estado Nacional e os povos indígenas no Brasil. Eu delineio a Bioética Intercultural Crítica como um diálogo com a "interculturalidade crítica” (Walsh 2010 \& Viana 2010), no caso, ao imaginário eurocêntrico que pressupõe que os povos da floresta e as mulheres, além de inferiores, são seres de carência, inclusive de palavras de sabedoria, de discernimento e de ética (Cemin 2011).
A prática do discurso é constitutiva da organização social dos povos da floresta, seringueiros, ribeirinhos, quilombolas e indígenas (Cemin 2011). Essa prática fundamenta sua sociabilidade e filosofia (Clastres 1979). A resolução de conflitos pela mediação discursiva, também foi constatada na pesquisa aqui relatada e em outras. Esses povos não vêem a conversa entre si e com os demais como perda de tempo; ao contrário, acentuam a necessidade de que as "pessoas grandes", autoridades e cientistas, esclareçam as leis e demais questões que os afetam. Valorizam a oralidade, a narrativa e a "ajuda" simétrica, solidária (Cemin 2001, Cemin \& Ott 2008). Entretanto, políticas pautadas por essa ética exigem a descolonização de nosso imaginário (Cemin 2011) e "pesquisa sobre o conflito das interpretações, a exemplo da que ocorre entre a visão medico Ocidental, materialista, e a medicina indígena, "espiritualista (Cemin 2015).

A gestão das políticas e dos sistemas em "códigos interculturais" exige a descolonização, e a "interculturalidade emancipadora", como defende Boaventura (2009); pois o "bem viver", filosofia indígena e camponesa ancestral, pouco tem a ver com o uso utilitarista, individualista, antiecológico e materialista que o monismo ideológico lhe empresta (Alcoreza 2010, 2012). O Brasil inscreve o pluralismo e o direito à diferença em sua constituição, mas esse direito não prepondera em relação aos povos indígenas (Segato 2011). A Bioética aqui proposta pressupõe o questionamento da "tradição", em ambas as culturas, indígena e não indíge- 
na. As sociedades são dinâmicas, e cabe aos seus membros determinarem o que mudar e o que preservar, considerando suas éticas de bem viver (Segato 2011, Alcoreza 2010, 2012). Destaca-se aqui o questionamento do poder masculino para "correção" violenta do comportamento feminino, caso das violências, onde se inclui o estupro coletivo ou individual, bem como se registra a agencia das mulheres indígenas no enfrentamento da questão, a partir do pensamento feminista acessado pelas mulheres indígenas que atuam na esfera dos movimentos sociais (Sacchi 2009, Sacchi \& Gramkow 2012, Souza \& Cemin 2012).

O termo "intercultural é um conceito em disputa que visa ir além do multiculturalismo, sendo, entretanto, herdeiro de suas conquistas e limites em pelo menos três frentes de lutas: por educação, pelos direitos das mulheres e por reivindicações identitárias (Semprine 1999), a exemplo do movimento de negros e de indígenas. Surge na confluência de diferentes eventos, como o movimento indígena por educação bilíngue, várias normativas internacionais, como o Convênio 169 da OIT, e de diferentes movimentos sociais; reforçados por Declarações da UNESCO sobre a defesa e a proteção da Diversidade Cultural; além de críticas teóricas ao multiculturalismo funcional e/ou segregacionista. No contexto latino americano o termo se espraia da educação para diferentes áreas do conhecimento (Política, Filosofia e Teologia). Abarca pelo menos três dimensões com interações complexas. Primeiro uma dimensão relacional, de interação da diversidade étnico e cultural e assim, sempre teria existido. Nessa compreensão, o termo "etno" conota a diferença cultural e reúne a diferença cultural ao fator "racial", no sentido fenotípico. A segunda dimensão, é a de um sentido estatal e burocrático de cunho funcionalista que preconiza ausência de conflito entre grupos culturais distintos e assim reproduz a integração subordinada, uma vez que obscurece as relações de poder entre raças, etnias, gêneros e classes sociais. A terceira, é o sentido de interculturalidade crítica, contra-hegemônica que indica que a diferença se constrói enquanto relação racializada, de superioridade hierárquica do Norte sobre o Sul. Por isso discute e demanda transformações nas estruturas de dominação epistêmicas, políticas, jurídicas e éticas (Quijano 2007; Walsh 2010). Visa não apenas os povos indígenas, mas todos os grupos étnicos sejam eles considerados em dimensão cultural ou cultural e fenotípica. Este terceiro sentido é o adotado nesse artigo.

Além deste sentido crítico, considera-se o caráter relacional do conceito de interculturalidade enquanto "zonas de contato", ou seja, "situações mais ou menos permanentes de interculturalidade", que configuram "campos" e "redes" de relações interculturais diversificadas desde relações domésticas e cotidianas, até instituições estatais, religiosas ou empresariais (Montero 2006). O tema da interculturalidade conjuga um amplo complexo de questões em torno da noção de identidade étnica ou cultural, de longa tradição na antropologia, expressos em conceitos 
como "aculturação", "transfiguração" e "fricção" étnica, além dos problemas de expansão de fronteiras e de colonialismo interno (Athias 2007). Fala-se, portanto, da dinâmica produzida nas relações interculturais, não no sentido de uma funcionalidade harmônica, mas reconhecendo que elas podem assumir além de caráter simétrico, feições de intolerância, injustiça, desigualdade e violências diversas.

Políticas de gênero envolvem sensibilidade à diferença, as posições de poder e de divisão do trabalho social. No caso de sociedades indígenas "a ordem tradicional" se estrutura social e culturalmente em "relação complementar entre os sexos", razão pela qual as políticas públicas deverão intervir seletivamente nessas estruturas, visando preservar ou alterar o que a comunidade assim o desejar. Ao mesmo tempo, ao considerar que nenhuma sociedade é a expressão de uma funcionalidade harmônica e que em todas elas as mulheres são consideradas um grupo com interesses específicos e com potencial faccioso, coloca-se para o movimento indígena o desafio de proteger as mulheres e ao mesmo tempo produzir mudanças naqueles aspectos estruturais que favorecem a dominação masculina (Segato 2003a).

Reunidas pela FUNAI em Brasília, no ano de 2003, com o objetivo de exporem seus problemas e soluções, as mulheres indígenas indicaram também o desequilíbrio provocado pela intervenção do Estado e de ONGs, nas relações sociais de gêneros dos povos indígenas, dado a baixa participação das mulheres nas posições de poder que estas agências criam através de seus programas. Ao serem esses lugares majoritariamente ocupados por homens, "redobram" o papel de prestígio das tarefas tradicionais masculinas. Entretanto, entidades governamentais e não governamentais esboçam intenções no sentido de promover correções de rumo nessa política (Segato 2003a). Um exemplo disso foi a fala do Presidente (antropólogo) da FUNAI, ao reconhecer que o "indigenismo brasileiro tem um enfoque muito masculino" (Segato 2003:46). E o Gerente Técnico do PDPI (Projetos Demonstrativos dos Povos Indígenas), Gersem dos Santos Luciano Baniwa, disse que "via na mobilização das mulheres uma oportunidade para revitalizar o movimento indígena como um todo" (SEGATO 2003:46).

A compreensão expressa por Gersem Baniwa encontra ressonância com a etnologia das terras baixas da América do Sul que questiona oposições conceituais a exemplo de público e privado em associação prévia e fixa entre masculino e feminino (Viveiros de Castro 1993); e também com a teoria feminista que problematiza tanto a universalização absoluta da dominação masculina quanto à noção de sociedade monolítica e delimitada rigidamente (Strathern 2006). Em muitos aspectos a organização social depende dos modos de construção dos gêneros, como na produção, reprodução, distribuição e troca, o que implica enfocar a importância das agências masculinas, mas também femininas, no sentido de analisar a relação entre a construção do gênero e da mudança cultural (Rodri- 
gues 1999, Mccallum 1999, Gow 1989, Lea 1999, Lasmar 2005, 2009, Ferreira 2009). Considera-se o confronto biopolítico ocidental e não ocidental, onde se pode inscrever outra noção de humanidade (Fassin 2017) em grande parte disfuncional ao Estado, ao Mercado capitalista e ao patriarcado (Segato 2011b). Assim, a proposta se insere na perspectiva da crítica social instituída pelo feminismo, no campo da Bioética Feminista (Bandeira \& Almeida 2008, Diniz 2011, Diniz \& Vélez 1999).

Feminismo e Bioética são campos co-emergentes e confluentes na abordagem da "condição humana" (Bandeira \& Almeida 2008:16) na modernidade. São vertentes contra hegemônicas, que abordam questões tais como exclusão social e assimetrias de poder nas relações entre nações, gênero, raça, etnia e classe, colonialismo e "imperialismo moral" reivindicando pluralismo moral e direito à diferença, inclusive epistemológica, no sentido de uma reflexão bioética própria aos países do Sul (Garrafa 2008, Diniz 2008, Diniz \& Vélez 1999, Bandeira \& Almeida 2008).

As políticas públicas de educação escolarizada nos campos do ensino e da saúde precisam manter correspondência com os interesses de reprodução das sociedades: saúde, justiça, economia e segurança da vida comunitária. $\mathrm{Na}$ cena 4, veremos o envolvimento de professor indígena em estupro praticado em grupo. Entretanto, a cena ali entrevista permite, perceber "fissuras" no "mandato de violação" (Segato 2003) de mulheres, no caso, o recuo do professor na efetivação do ato. As mulheres indígenas se mobilizam por transformações em defesa de sua integridade e de seus povos. Potencializar as políticas públicas para as transformações desejadas seria o desafio de políticas interculturais.

\section{COLONIALIDADE E VIOLÊNCIA CONTRA A MULHER INDÍGENA: SAÚDE COLETIVA E JUSTIÇA}

O contato das populações indígenas do Vale do Rio Guaporé com os colonizadores remonta aos séculos XVII e XVIII. A economia de extração das "drogas do sertão" e do látex da Hévea brasiliensis, na Amazônia, nos séculos XIX e XX fundamentou-se em sistemático padrão de violência para expropriação da força de trabalho. Trata-se de população habitante em área de extensa fronteira com a Bolívia e seus notórios e seculares problemas de tráfegos, disputas e tráficos diversos. Os avanços das diferentes fronteiras econômicas: extrativista vegetal, mineral, madeireira e agrícola, e os atuais projetos desenvolvimentistas reatualizam perdas e a ressignificação étnica forçados pela "colonialidade do poder" (Quijano 1992). Ou seja, padrões de dominação e exploração econômica e epistêmica sustentados por relações de classe e de raça, sendo a racialização hierárquica o substrato de sustentação da exploração econômica, da violência e da dominação cultural (Quijano 1992, Segato 2014).

Os padrões atuais de violência contra a mulher indígena foram reforçados e mesmo forjados no longo período de contato para a subjugação dos indíge- 
nas ao trabalho. As relações sociais na economia extrativista foram pautadas pela violência física e simbólica. $\mathrm{Mu}-$ lheres indígenas foram retiradas à força de seus ambientes por gerentes de seringais e capatazes para serem "entregues" a seringueiros considerados mais produtivos que usufruíam delas enquanto prestadoras de serviços sexuais, domésticos e de extração do látex, entre outras tarefas, a exemplo da pesca de subsistência e da atenção ao parto e ao adoecimento (Woolf 1999) e cenas 5.6 .7 e 8 , adiante. Muitas delas foram "amansadas" depois de terem sido apresadas nas "correrias": expedições organizadas para captura e escravização de indígenas. Os métodos de amansamento consistiam em mantê-las amarradas e amordaçadas por longos períodos. Algumas recusavam alimento por vários dias e empreendiam fugas como forma de resistência aos seus captores (Woolf 1999) e Cenas 5, 6, 7 e 8, adiante.

Do mesmo modo, em GT/ABA/1994, (Coordenado por Vanessa Rosemary Lea), Simonian (1994), apresentou um paper onde relata diversas formas de violência contra as mulheres indígenas, ao tempo em que questiona o silêncio sobre o tema. Do mesmo modo, Vilaça (1992) indica que o casamento entre os Wari assinala o momento crítico entre afinidade e parentesco cognato. Descreve uma cerimônia de casamento que presenciou, na qual os discursos dos parentes dos noivos recomendam que o esposo não bata na mulher. Descreve também o modo ritual de resolução de conflitos, inclusive decorrentes de acusação de adultério feminino, pelo rito "mixita" (briga de borduna) que confronta os parentes do casal, no qual os parentes defendem a mulher e resolvem as contendas.

Violação sexual é caso de saúde pública e coletiva, pois saúde e doença são processos que decorrem não apenas de fatores biomédicos, mas da dinâmica sociocultural do ambiente. No caso aqui analisado, a desagregação socioambiental dos povos indígenas e a proibição de reatualização de suas cosmologias, produzem "patologias do simbólico", visto que o imaginário é fator de equilíbrio psicossocial (Durand 2000). A relação social de gênero em desequilíbrio, afeta à base da reprodução social do grupo: iniciação sexual e matrimônio, divisão do trabalho, autoridade e status.

Destaca-se nas cenas apresentadas, primeiro, a abordagem insuficiente dos agravos à saúde, pois o exame para atestar "conjunção carnal", violenta ou não, nem mesmo tangencia a subjetividade das examinadas, cuja complexidade cresce frente à incompreensão e ao preconceito étnico. A simbólica social de atribuição de valor da masculinidade ou feminilidade, as rupturas dos laços étnicos e de vizinhança, a impotência da vítima, de seus "parentes", e das etnias, escapam também a esse tipo de exame. Estas questões seriam passíveis de Laudo Antropológico, mas com a configuração atual das equipes médicas, que não contam com antropólogos (as); e do judiciário, com quadro reduzido, no mínimo, o laudo demora a ser feito. Na prática, o que se considera são apenas as marcas físicas no corpo da vítima. Além disso, dado 
as relações de poder, não necessariamente, são os casos mais graves que chegam aos sistemas de saúde e de justiça, conforme a contraposição entre os Inquéritos Policiais e as entrevistas permite constatar.

Segundo. Nos casos denunciados, a idade de início de atividade sexual das vítimas varia entre 8 e menos de 13 anos, sendo que os acusados têm mais que 10 anos de idade com relação a elas. Vários problemas podem ser elencados quanto à idade no que se refere à pauta da diferença e do respeito à diversidade cultural e ao pluralismo jurídico. A Lei 12.015/2009 estabelece como crime, a prática de sexo com menor de 14 anos, independente do uso de violência, do consentimento e da "vida pregressa" da menor; o ato é considerado "estupro de vulnerável", passível de pena de prisão. Mas como equacionar o fato de que as relações sexuais entre os indígenas iniciam em idade abaixo do que é previsto na legislação? A idade não deve ser isolada das regras e das práticas que orientam as relações de namoro e matrimônio nas diferentes sociedades. Inclusive, na atualidade, diante da constatação de prática sexual entre meninas com menos de 9 anos de idade, em etnias não indígenas, pesquisadores da saúde e do judiciário argumentam pelo irrealismo da Lei 12.015/2009. Além disso, situações novas se apresentam na condição de crianças e adolescentes indígenas: exigência de escolaridade, emprego e renda, ao mesmo tempo em que ocorre a desvalorização do trabalho na roça. $\mathrm{O}$ que se verifica, apesar da incompletude dos dados, é a defasagem entre idade, escolaridade e profissionalização.

Terceiro. No que diz respeito às relações amorosas, há confronto entre o modelo tradicional que prevê a escolha do parceiro pelo pai da moça e o modelo não indígena, no qual é o indivíduo quem decide a partir de preferência pessoal. Conflitos se estabelecem quando os pais não aprovam a escolha, seja pelo caráter do pretendente ou por inimizades étnicas. Qual seria a influência dos fatores étnicos, da inimizade pessoal e da desaprovação social nas agressões sexuais? Como reorganizar regras e efetivar o diálogo intercultural frente à tensão entre lógicas étnicas distintas, de índios entre si e de não índios? Entre o individualismo jurídico e as regras de status?

Quarto. O valor dado à maternidade na cultura indígena confronta o fenômeno da "mãe solteira", com grave repercussão nas inimizades e nas violências. Os rapazes, em função do atual enfraquecimento da autoridade parental institucionalizada, facilmente escapam do reconhecimento da paternidade e da relação de casamento. É frequente que as jovens digam que o pai não quis assumir, disse que não sabe se o filho é seu. Como justificativa para não assumir a paternidade, os rapazes alegam a fala de suas mães alertando-os de que a criança pode não ser seu filho. Ou seja, a influência parental, não desaparece com o enfraquecimento institucional do poder familiar.

Quinto. Outra situação inusitada se apresenta no que diz respeito aos rapazes, pois são considerados "desocupados" que circulam pelas aldeias, às ve- 
zes de moto, excedendo-se em álcool e outras drogas, "perseguindo" as crianças e as adolescentes ou no ócio, em torno dos "aparelhos de som".

Sexto. O tipo de relação entre vítimas e acusados é de intimidade amorosa, étnica ou, no mínimo, de vizinhança, conforme quadro abaixo, excetuando-se a cena 01 em que a agressão foi feita por dois homens supostamente desconhecidos. Porém esses laços sociais são incapazes de garantir a integridade física das mulheres, expressando, ao contrário, práticas de violação. No caso da cena 02 a relação de namoro foi confirmada pelo casal, mas a moça havia sido estuprada pelo padrasto quando tinha 8 anos de idade. $\mathrm{Na}$ cena 03 há confirmação de ambos sobre ter existido namoro, mas, a partir do "estupro" a informação sobre o romance diverge: a moça disse que rompeu em resposta à agressão sofrida, e o acusado diz que a relação se prolongou por mais tempo. Na cena 04, a criança de 11 anos de idade não confirma a relação de namoro, diferentemente do acusado que acrescenta não ter sido o primeiro a ter relação sexual com a menina.

Tabela 1 - Tipo de relação vítimas/agressores

\begin{tabular}{|c|c|c|c|c|c|c|c|c|c|}
\hline \multirow{2}{*}{ Cena } & \multicolumn{2}{|c|}{ Idade } & \multirow{2}{*}{ Relação } & \multirow{2}{*}{$\begin{array}{c}\mathrm{N}^{\mathrm{o}} \\
\text { Agres- } \\
\text { sores }\end{array}$} & \multicolumn{2}{|c|}{ Etnia } & \multirow{2}{*}{$\begin{array}{c}\text { Local / } \\
\text { Agressão }\end{array}$} & \multicolumn{2}{|c|}{ Residência } \\
\hline & $\mathrm{Vt}^{*}$ & Ag & & & $\mathrm{Vt}^{*}$ & Ag* & & Vit. & Ag* \\
\hline 01 & 13 & $\tilde{\mathrm{n}} / \mathrm{c}$ & Estranhos & 02 & Wari & $\tilde{\mathrm{n}} / \mathrm{c}$ & $\begin{array}{l}\text { Estrada p/ } \\
\text { Surpresa }\end{array}$ & $\begin{array}{c}\text { Aldeia } \\
\text { Sagarana }\end{array}$ & $\begin{array}{c}\tilde{\mathrm{N}} \text { foi } \\
\text { identificado }\end{array}$ \\
\hline 02 & 18 & 21 & Namorado & 01 & $\begin{array}{c}\tilde{\mathrm{N}} \\
\text { índia }\end{array}$ & Makurap & $\begin{array}{l}\text { Guajará } \\
\text { Mirim }\end{array}$ & $\begin{array}{l}\text { Guajará } \\
\text { Mirim }\end{array}$ & $\begin{array}{c}\text { Aldeia Ricar- } \\
\text { do Franco }\end{array}$ \\
\hline 03 & 13 & $\begin{array}{c}20 \\
36 \\
\tilde{n} / c\end{array}$ & $\begin{array}{c}\text { Ex- } \\
\text {-namorado }\end{array}$ & 03 & Wari & Wari & $\begin{array}{l}\text { Aldeia } \mathrm{Ca}- \\
\text { poeirinha }\end{array}$ & $\begin{array}{l}\text { Aldeia } \mathrm{Ca}- \\
\text { poeirinha }\end{array}$ & $\begin{array}{l}\text { Aldeia Rio } \\
\text { Negro Ocaia }\end{array}$ \\
\hline 04 & 11 & 22 & $\begin{array}{c}\text { Namorado } \\
\text { (?) }\end{array}$ & 01 & Wari & Wari & $\begin{array}{c}\text { Aldeia Rio } \\
\text { Negro } \\
\text { Ocaia }\end{array}$ & $\begin{array}{c}\text { Aldeia Rio } \\
\text { Negro } \\
\text { Ocaia }\end{array}$ & $\begin{array}{l}\text { Aldeia Rio } \\
\text { Negro Ocaia }\end{array}$ \\
\hline \multicolumn{10}{|c|}{ Entrevistas na aldeia } \\
\hline 05 & & & Namorado & 01 & $\begin{array}{l}\text { Maku- } \\
\text { rap }\end{array}$ & Jabuti & $\begin{array}{c}\text { Ricardo } \\
\text { Franco }\end{array}$ & $\begin{array}{l}\text { Ricardo } \\
\text { Franco }\end{array}$ & $\begin{array}{c}\text { Ricardo } \\
\text { Franco }\end{array}$ \\
\hline 06 & & & Namorado & 03 & & Wari & São Luiz & São Luiz & São Luiz \\
\hline 07 & 19 & & $\begin{array}{c}\text { Ex- } \\
\text {-namorado }\end{array}$ & 03 & & Wari & $\begin{array}{c}\text { Guajará } \\
\text { Mirim }\end{array}$ & & \\
\hline 08 & 13 & & Namorado & 01 & & Wari & ------- & & \\
\hline
\end{tabular}

Legenda: Vt. = vitima. Ag. = agressor

Sétimo. Quanto ao "estupro" a situação não é menos complexa: na cena 01 , tentativa de estupro por dois homens "desconhecidos" contra uma adolescente de 13 anos. Na cena 02, o estu- pro foi negado pela moça, mas infelizmente não resultou em alívio, pois ela havia sido estuprada por seu padrasto, aos 8 anos de idade. Ele saiu ileso da situação porque a mãe da então crian- 
ça não a defendeu apenas a afastou de casa um tempo depois, e persistiu na relação amorosa com o agressor, propiciando que ele continuasse o delito. A cena 3, caso de agressão em grupo, mostra a inominável prática masculina de usar o sexo como arma para castigar mulheres. Em muitas sociedades é prática regulamentada, fazendo parte da estrutura sociológica, por isso, não é tida como desvio, porque as relações de gênero operam com o sistema de status, apesar do contrato jurídico típico do individualismo moderno (SEGATO 2003)

Oitavo. A delicada questão do desejo sexual, particularmente quando diz respeito a crianças e adolescentes, como é o caso da Cena 04, envolvendo uma criança de 11 anos, acusada pelo abusador de ter vida sexual pregressa. Há que se considerar ainda, que os aspectos de realização pessoal, através de namoro e de matrimônio não são passíveis de equacionamento pelo tipo de abordagem clínica, policial e jurídica atual. Ao contrário, requerem estudos multidisciplinares e de longo prazo, com especial atenção à cultura, que é a dimensão constitutiva da subjetividade humana. Seria o caso de analisar o "mandato de violação", para dar conta dos interlocutores ocultos, dos quais o sujeito quer obter poder. Segato (2003) utiliza essa noção para falar da subjetividade do agressor, mas entendo que a noção pode ser expandida para dar conta de normas culturais generalizadas.

Nono. O caso da cena 3 evidencia que apesar do estupro em grupo como vingança e corretivo à mulher, mudanças são entrevistas, pois os dois rapazes convidados não concluíram o combinado, sentiram "dó” da vítima. Como reforçar os fatores para as mudanças positivas? Descolonizar o nosso imaginário sobre os povos indígenas seria condição básica para a instituição de uma interculturalidade simétrica, embasada na reflexividade e agencia dos próprios indígenas. Vejamos trechos de entrevistas de três homens e de uma mulher indígena que expressam as transformações em curso (Cemin \& Ott 2008):

a) "Eu bati na minha mulher porque apanhei dela primeiro, mas me arrependi, não devia ter feito isso, foi feio, não gosto nem de lembrar. No dia da briga estava só nos dois. Ela foi embora para Brasília e está na universidade fazendo Assistência Social para defender as mulheres”.

b) "Com minha atual mulher, no começo foi difícil, um empurrava o outro, mas nunca ferimos um ao outro. Aos trinta e poucos anos comecei a beber de forma moderada. Vimos que somos educadores (ambos são professores), espelhos da comunidade e das crianças. Resolvemos parar com as brigas. Digo para ela, você estudou, tem o direito de conversar com quem você precisar. Tem que ter diálogo".

c) "Casamento indígena não é violento porque hoje em dia a gente vê no jornal a Lei Maria da Penha. Wari aprendeu essa lei. 
Não adianta espancar a mulher porque as crianças aprendem. Antes usava arco de pupunha e aquele que usava de violência os pais puniam. No Rio Negro Ocaia é mais tranquilo pela organização do cacique que faz reunião para não fazer bagunça e a aldeia levar nome feio. De vez em quando acontece violência mais só de vez em quando. A lei é do cacique e usar a violência de espancar não adianta, complica a vida da mulher, da família dela e do homem".

d) Mulher indígena: "O estudo foi à maravilha que Deus me deu. Eu aos 15 anos queria imitar os não índios e não valorizava minha cultura. No Açaí (programa para formação de professor/a indígena) eu retomei a minha cultura e aprendi a valorizar. Meu segundo marido (diz o nome) me batia e queria me matar e eu dei parte dele na Delegacia de Defesa da $\mathrm{Mu}-$ lher (DDM) só para assustar, não queria que ele fosse preso porque não fica bem. Pedi a separação e a pensão e ele recuou e nosso casamento agora está bem".

Décimo. A necessidade de repensar o monismo nas diferentes áreas fica evidente diante do despreparo dos agentes do Estado na assistência, defesa e prestação de serviços aos indígenas. Há reforço da ideologia de desqualificação do mundo indígena que, iniciando no Inquérito Policial, supostamente objetivo enquanto gênero discursivo
(Biazzoto 2006) reverbera e espraia o preconceito étnico. O que pode ser visto através da CENA 4 é uma continuidade discursiva que vai dos agentes indigenistas (assistente social e chefe de Posto Indígena/FUNAI) ao Procurador do Estado, em reforço do imaginário colonial, estabelecido nos séculos XV e XVI, de que as sociedades indígenas configuram povos sem lei, sem moral, e nenhum costume.

Décimo primeiro. O apelo social aos procedimentos punitivos prepondera. Entretanto, a educação e a transformação nas condições econômico-sociais são mais eficazes, a médio e longo prazo, pois a violência é a expressão de várias dinâmicas entrelaçadas; exige abordagem cultural sensível, conversação dissuasória, pessoal e coletiva baseada em outra ética, de menos punição e mais assistência e diálogo simétrico. Além de alinhamento entre as políticas públicas Federal, Estadual e Municipal, pois sendo as políticas públicas, expressão do direito, sua formulação e execução requerem pluralismo jurídico e bioético em atenção à estrutura e organização social dos afetados; bem como articulação entre justiça, polícia, saúde, economia, educação, assistência social, religião e moral; pois a vida social é multidimensional, trata-se, em termos prático, teórico e metodológico, daquilo que Mauss (1974) denomina "fato social total".

\section{CONCLUSÃO}

Os dados dizem respeito a culturas pouco conhecidas, no que pese o fato de uma ou outra ter sido estudada. São 
povos com mais de quatro séculos de contato, ora intenso, ora intermitente com os colonizadores europeus e nacionais. Esse processo é multifacetado, destacando-se a resistência e a criatividade desses povos para a sua salvaguarda física e cultural. Isso é possível, como em qualquer processo de luta social, com a ajuda de aliados a exemplo de pessoas e de instituições as mais diversas. O que se propõe é uma variante da "Bioética de Intervenção", visto que ela é consequente com uma ciência socialmente comprometida.

A Bioética aqui proposta implica em aliança política com os "povos da floresta”, pautada em crítica aos imaginários e as práticas que os desqualificam e em ações que possam potencializá-los para o enfrentamento de seus problemas. Isto requer amplo processo educativo de todos os envolvidos e no limite, abarca o local, a Nação e o espaço transnacional. O despreparo dos agentes do Estado na assistência e prestação de serviços aos indígenas vem sendo apontado, não sem razão. Vimos à reprise do imaginário colonial, estabelecido nos séculos XV e XVI: as sociedades indígenas configuram povos sem "lei, sem moral, e nenhum costume". Ou quando se admite que eles os tenham, são costumes tido como "horríveis". É preciso evitar que, em nome da necessária defesa dos Direitos Humanos, criminalizações injustas ocorram.

Os desafios postos pela "Antropologia por demanda" não são passiveis de elucidação por pesquisadores isolados atuando nos limites temporais de suas importantes dissertações e teses, porque os desafios dizem respeito ao conjunto da vida social e não a aspectos isolados. Requerem interpretações, mas também soluções passíveis de enfrentamento por pesquisas coletivas permanentes, projetadas para a reconstituição de longas séries históricas e estruturadas por equipes atuantes no tempo presente e em contínuo monitoramento da dinâmica contextual. Por isso, propõe-se como interface prática e teórica da Bioética Intercultural Crítica e Feminista, um Observatório dedicado à pesquisa, ensino e defesa Bioética dos "povos da floresta", a partir de questões de bioética e interculturalidade que leve em conta o debate feminista. $\ddot{E}$ necessário a compreensão das dinâmicas sócio-antropológicas das relações sociais de gênero; bem como dos conflitos e modos de resolução, inclusive violentos; para a apreensão das éticas e das concepções de ética e de justiça nos diferentes contextos étnicos

\section{CENAS, CENÁRIOS E PERSONA- GENS}

\section{NÃO HÁ CAMINHOS SEGUROS... (CENA 1. DM/GM. IP 018/2010).}

Arlete tem 13 anos, é da etnia Wari e reside às margens do Rio Guaporé, na área Indígena Sagarana, administrada pela Igreja Católica, através da Diocese de Guajará Mirim. A tentativa de estupro ocorreu na estrada que liga a Terra Indígena Sagarana ao Distrito Surpresa. Esse Distrito é circunscrição de Guajará Mirim e fica próximo da Área Indígena Sagarana e da Terra Indígena Guaporé, também chamada de Ricardo Franco. 
A adolescente saiu de casa pedalando uma bicicleta, no dia 15 de janeiro de 2010, rumo ao Distrito Surpresa para realizar compras a pedido de sua mãe. No retorno foi agarrada por dois homens que vinham em suas respectivas motocicletas. Ela foi jogada ao chão, o pneu de sua bicicleta foi furado, recebeu chutes enquanto era despida, e desmaiou. Não pode reconhecer os agressores, pois estavam com o rosto coberto com um pano. Com a aproximação de um senhor idoso e desconhecido, os agressores fugiram e deixaram as duas motocicletas. $\mathrm{Na}$ delegacia, Arlete falou que é "virgem", que não tem condição de identificar os agressores, e que eles não pronunciaram nenhuma palavra enquanto a agrediam. Ela informou também que não foi roubada.

\section{A MÃE DE ARLETE}

Ao prestar declaração na Delegacia da Mulher, a mãe de Arlete, 40 anos, pertencente a outro clã da mesma etnia (Wari) que a filha, confirma que Arlete saiu de casa ao 08h00min para fazer compras em Surpresa e retornou as $16 \mathrm{~h} 00 \mathrm{~min}$, relatando a agressão e o modo como foi salva por um senhor, que localizou a bicicleta e as compras e a levou para a casa dos parentes em Surpresa, e posteriormente a transportou em barco para Sagarana, acompanhada pelo cacique.

\section{AGRAVOS À SAÚDE}

Uma funcionária do Conselho Indigenista Missionário, CIMI, que acompanhou a mãe de Arlete à Delegacia, esclareceu que a menina apresentou estado febril, dificuldade para andar e marcas de agressão no rosto, no ombro, nas costas e no quadril.

\section{INFORME MÉDICO}

Relata que o hímen de Arlete se apresentava integro, embora com orifício amplo. Não sendo possível concluir sobre a sua condição de virgem, dado a existência de hímens complacentes. Acrescenta que não havia sinal de cicatriz recente ou antiga.

\section{O ESTUPRO HAVIA OCORRIDO BEM ANTES... (CENA 2. DM/GM. IP. 006/06).}

Carlos Makurap, 21 anos de idade, é filho de pai e mãe Makurap, e seu avós maternos e paternos também são da Etnia Makurap. Reside na Aldeia Ricardo Franco, Terra Indígena Guaporé, mas tem casa em Guajará Mirim, onde foi acusado de estuprar (Cena 2) Francisca, não-indígena, 18 anos. A denúncia foi feita pelo tio da moça.

Francisca, entretanto, declarou que conhece Carlos há um ano, que manteve relações sexuais com ele, mas não foi forçada, pois são namorados desde que se conheceram. Ele não foi o primeiro homem na vida dela porque ela foi estuprada pelo padrasto, na cidade de Porto Velho, quando tinha 8 anos de idade. Sua mãe flagrou esse estupro, mas não o denunciou à polícia. $\mathrm{Na}$ ocasião, mandou Francisca para a casa de uma tia, em Guajará Mirim, informando-a do problema. Mantém o caso amoroso com o estuprador da filha, mesmo sabendo, inclusive, que ele tem uma esposa. Após o estupro, o 
padrasto teria feito sexo com Francisca em pelo menos mais quatro ocasiões.

Quanto ao seu envolvimento com Carlos, eles fizeram sexo várias vezes, algumas com camisinha, e sempre na residência dele, de dia ou de noite. A Mãe de Carlos sabia e via quando ela entrava no quarto dele, que a última vez que fizeram sexo foi há menos de uma semana da denúncia. Ela gosta muito de Carlos, mas soube que ele faz sexo com outras mulheres, incluindo a sua cunhada. Mas reafirma que sempre fez sexo com ele por livre vontade. Uma nota esclarece que a mãe de Francisca sabe que ela faz sexo com Carlos, mas não deseja representar contra ele.

\section{AGRAVOS À SAÚDE}

Não há registro sobre qualquer dano.

\section{INFORME MÉDICO}

O laudo pericial atesta que não há sinal de desvirginamento recente, e que a mesma não é virgem.

"UMA GERAL" EM GRUPO: COMO VINGANÇA E CORRETIVO... (CENA 3. DM/GM. IP 019/2004).

\section{SANDRA}

Sandra é da etnia Wari, tem 13 anos e frequenta a $4^{a}$ série. Foi vítima de estupro, na localidade Capoeirinha, Aldeia Tanajura, em Guajará Mirim. A agressão foi praticada por Marcos, pertencente a outro clã da mesma etnia que Sandra e mais dois homens: um do mesmo clã que o Marcos, e o outro, um adolescente, pertence ao clã de
Sandra. Foi desvirginada pelo namorado há mais de um ano, mas não deseja citar o nome dele. No dia em que foi estuprada, estava pescando com um de seus sobrinhos, 10 anos de idade, e o Marcos estava jogando bola com os dois rapazes que também participaram do estupro. Diz que foi agarrada pelo braço e levada para o mato onde foi deitada no chão. $\mathrm{O}$ sobrinho ouviu o seu grito e chegou a bater nos rapazes com uma vareta, sem conseguir detê-los. Um dos rapazes tirou-lhe a roupa íntima, deixando-a com a saia e a blusa, depois segurou os seus pés, o outro tapou a sua boca, enquanto Marcos (e apenas ele) fez sexo com ela. Não sofreu ameaça por arma e os outros dois rapazes se retiraram logo após o sexo praticado por Marcos.

Marcos a manteve presa, fez sexo com ela várias vezes, mas por volta das 06:00 do dia seguinte, conseguiu ir para casa. Não foi agredida fisicamente, e estava namorando o Marcos por quase três meses e já tinha feito sexo com ele por duas vezes, sem ter sido coagida. Mas o recusou quando ele a procurou pela terceira vez. Acredita que por isso ele agiu dessa forma, razão pela qual ela não quer continuar o namoro com ele.

\section{A MÃE DE SANDRA}

A mãe de Sandra é da etnia Canoé e nasceu na Aldeia Ricardo Franco, mas sendo casada com Wari, foi residir na Aldeia Capoeirinha, no Rio Pacaas. Declara-se agricultora e analfabeta e apresenta denúncia contra os infratores. 


\section{MARCOS}

Marcos tem 20 anos, é estudante da $7^{\mathrm{a}}$ série, vive com os pais, ambos Wari, é solteiro e não tem filhos. Mora na Aldeia Rio Negro Ocaia, onde nasceu. Conhece Sandra há um ano e são namorados há 11 meses. Mas fez sexo com ela há apenas dois meses, e a pedido dela, que não houve sangramento e tudo transcorreu sem coação por parte dele, se beijaram e abraçaram e a própria Sandra tirou as vestes.

Entretanto, há cerca de 20 dias ficou sabendo que Sandra fez sexo com outro homem e ele diz que ficou indignado e resolveu se vingar. Comentou o seu plano com os dois amigos, convidando-os para darem "uma geral nela", e eles teriam concordado. Sandra estava pescando e o chamou, ele se aproximou e fez sexo contra a vontade dela. Os seus dois amigos seguraram Sandra, mas não fizeram sexo com ela, talvez por medo, pois tinham combinado "dar uma geral".

Quando Marcos terminou de fazer sexo com Sandra, os dois rapazes foram embora, ficando apenas ele e Sandra, que disse que pretendia fugir com ele e o segurou pela camisa para que ele não se afastasse, e assim, ficaram juntos até o dia seguinte as 5:00 da manhã. Nesse período fizeram sexo várias vezes. Sandra disse que os pais dela são contra o namoro deles, por isso ela queria fugir. Ele recusou o plano de fuga. Ele e Sandra continuam namorando escondidos, está arrependido do que fez, não utilizaram armas, mas ela chorou quando ele fez sexo com ela à força com a ajuda dos amigos. Nunca foi preso ou processado.

\section{O PRIMO DE SANDRA}

O primo de Sandra, da etnia Wari, é estudante da $2^{a}$ série e tem 10 anos de idade. Naquele dia estava pescando com Sandra e ouviu Marcos chamando Sandra: vem cá, quero falar sério com você. Sandra foi até ele e os dois rapazes que estavam escondidos no mato apareceram e os três levaram Sandra para o mato. Ele disse que subiu em um barranco e ouviu Sandra dizer, Marcos, olha a meninada aí. Tentou encontrar Sandra, e não conseguiu. Foi para casa e contou o corrido para a sua mãe. Não foi agredido, não agrediu e nunca viu Sandra namorar.

\section{O AMIGO (JOSÉ)}

José, da etnia Wari, tem 36 anos, Magistério de $2^{\circ}$ grau, é funcionário público e professor. Viveu com os pais até 21 anos. É casado e tem um filho de 3 anos e uma filha com 1 ano e 7 meses. Mora na Aldeia Capoeirinha ("em casa de alvenaria"). Conhece Geraldo, desde criança e Marcos há 2 anos. Marcos comentou com ele que havia desvirginado Sandra e que tentou morar com ela, mas a família dela não permitiu. Estava revoltado. Ele aconselhou Marcos a não ficar chateado, pois tem muitas mulheres por aí. No dia em questão, ele estava jogando bola com Geraldo, Marcos e outros. Marcos comentou que Sandra havia arranjado outro namorado, mas ele queria ficar com ela, pois a tinha desvirginado. 
Enquanto jogavam bola viu que Sandra saiu de canoa para pescar, acompanhada pelo sobrinho. Marcos resolveu ir atrás dela por terra para fazer sexo e os convidou para também fazerem o mesmo. Transcorrido mais ou menos 1 hora, ele e Geraldo resolveram procurar o Marcos e o encontraram, fazendo sexo com Sandra. Ele estava sobre o corpo dela, tendo-lhe retirado apenas a peça íntima. Marcos pediu para ele segurar as pernas e os braços de Sandra e quando ele o fez, Sandra passou a se debater. Ele e Geraldo não fizeram sexo com ela porque ficaram com dó. Seguraram Sandra por poucos minutos e não aceitaram os insistentes apelos de Marcos para que eles fizessem sexo com Sandra. Ao ver o sobrinho de Sandra se aproximando, ele e Geraldo foram embora. Marcos e Sandra retornaram para as suas casas apenas as 04:00 do dia seguinte. Marcos comentou com ele que mandou a Sandra ir embora e ela não aceitou. Conclui dizendo que agiu errado e não vai mais fazer isso. Contou o que viu aos familiares de Sandra, e que estes revoltados ameaçaram matar o Marcos.

\section{OUTRO AMIGO (GERALDO)}

Geraldo é adolescente, seus pais são Wari, e ele é do clã de Sandra, estuda e reside na Aldeia Capoeirinha e conhece Sandra desde criança. Ela é uma moça comportada, namorou o Marcos e ele queria casar com ela, mas os pais dela não o aceitaram. Jogavam bola quando Marcos chamou a ele e ao José para darem "uma geral" em Sandra, pois esta o estava enganando e se dizendo grávida. Ele e José aceitaram a proposta. Marcos foi sozinho em Busca de Sandra que pescava junto ao sobrinho.

Algum tempo depois, ele e José encontraram Marcos e Sandra namorando no mato. Os dois seguraram as pernas e os braços de Sandra para que o Marcos fizesse sexo com ela que se debatia e chorava. Marcos não despiu Sandra, retirando-lhes apenas a peça íntima. Ele e José ficaram com dó e resolveram não dar a "geral nela". Com a aproximação do sobrinho de Sandra eles foram embora e Marcos ficou com Sandra. Está arrependido do que fez. É a primeira vez que vem a delegacia, não usa drogas e não bebe, não usaram arma para ameaçar a Sandra.

\section{A FUNCIONÁRIA DA FUNAI}

Informa que tem dúvida de que Sandra tenha sido estuprada "realmente". Conhece a Aldeia Tanajura e lá é bem descampado. José é professor nessa aldeia e ela o conhece de vista. Marcos é estudante na mesma aldeia, mas reside na Área Indígena Rio Negro Ocaia. Conhece Geraldo apenas de vista.

\section{AGRAVOS À SAÚDE}

"Não há sinais de violência".

\section{INFORME MÉDICO}

Não há sinais de violência. O hímen é ovalar, apresentando ruptura cicatriza$\mathrm{da}$ as 17, 18, 20 e 22:00, no sentido dos ponteiros do relógio. Discussão (sic). Toda rotura himenal cicatrizada tem mais de 10 dias para fins de padroniza- 
ção pelo IML. Conclusão: rotura himenal antiga. Não há vestígio de desvirginamento recente, nem de violência.

\section{A REVOLTA DO PAI É PORQUE A FI- LHA SÓ TEM 11 ANOS DE IDADE. (CENA 4. PF/GM. IP 012 , /2005).}

\section{O PAI}

O pai de Célia foi o denunciante do estupro. Ele é Wari, filho de pai e mãe da mesma etnia, agricultor, 48 anos, residente na Aldeia Rio Negro Ocaia, e sabe ler e escrever. Foi acordado por sua esposa, as 04:30, pois ela ouviu barulho de passos e pensou que algum de seus filhos pudesse estar saindo de casa. Verificou com a lanterna e viu que a sua filha Célia, de 11 anos, não estava na cama. Saíram em busca de Célia e depois de mais ou menos 30 minutos, viram uma pessoa sair correndo perto da casa do motor de luz. Ficou nervoso e pediu a sua esposa para ir até o local, onde ela se deparou com a filha sentada no chão. Levou-a de volta para casa e a questionou sobre o fato. Célia disse que Antônio Wari havia "mexido" com ela.

No mesmo dia levou Célia para um grupo de médicos que estavam realizando consultas na região e que um laudo de atendimento de enfermagem foi elaborado. Ele tem conhecimento que Antônio já “mexeu” com outras meninas da aldeia, inclusive tendo engravidado duas delas. Informou também que dois irmãos de Célia, de 7 e 8 anos de idade, já haviam visto outra tentativa de Antônio contra a sua filha.

\section{$\mathrm{A} M \tilde{A} E$}

A mãe de Célia é Wari, de clã distinto ao do marido, tem 35 anos de idade, "do lar", portadora de Carteira de Trabalho, residente na Aldeia Rio Negro Ocaia. Confirma o relato do marido. Acrescenta que perguntou a Célia porque ela não havia gritado, e ela disse que Antônio tapou a sua boca para que não gritasse.

\section{CÉLIA}

Tem 11 anos de idade e é estudante. Saiu de casa de madrugada para urinar, Antônio chegou, tapou a sua boca e a levou para o capim, onde a deitou no chão, tirou a sua saia e fez sexo. Não sentiu dor, pois o ato foi praticado devagar e sem violência. Após algum tempo sua mãe a encontrou e a levou para casa. Questionada, disse que Antônio havia "mexido" com ela.

\section{ANTÔNIO}

Antônio tem 22 anos, é solteiro, estudante, com $1^{\circ}$ Grau completo, residente na aldeia Rio Negro Ocaia, filho de pai e mãe Wari, pertencente a clãs distintos aos da família de Célia. Periodicamente vem a Guajará Mirim acompanhar a sua mãe, pois ela recebe aposentadoria.

Em sua versão ele não estuprou Célia. Naquela noite estava havendo uma festa na escola e durante o dia tinham acertado que a noite iria à casa dela para irem à festa. Chegou a 1:00 da madrugada e ela já o esperava na janela. Foram a festa e no retorno as $04 \mathrm{~h} 00 \mathrm{~min}$, perto da casa de Célia, deitou-se com 
ela no capim e fizeram sexo. Viu o pai de Célia procurando-a com a lanterna e saiu correndo. Já fez sexo várias vezes com Célia e continuam a manter encontros sexuais, pois são namorados. Atualmente, o pai de Célia o aceita e permite o namoro. Inclusive não foi o primeiro, pois Célia já teve outros namorados antes dele. Não tapou a boca dela, pois ela consentiu com o ato. Tem um filho de três anos, com uma índia que está com 18 anos de idade.

Dois meses depois, Antônio voltou a prestar depoimento, onde ele aparece caracterizado como tendo o $1^{\circ} \mathrm{Grau}$ Completo e sem profissão. Ratifica o seu depoimento anterior, mas diz que passou a namorar Célia após a acusação de estupro. Informa que não são mais namorados, que ele está sozinho e que o namoro durou dois meses porque o pai dela não gosta dele. Afirma que tem um filho e que não conhece a idade de Célia.

\section{O CHEFE DO POSTO INDÍGENA}

Nasceu e reside em Guajará Mirim, solteiro, 44 anos, Técnico em Agropecuária, Chefe do Posto Indígena Rio Negro Ocaia há dois anos. Conhece Antônio, que leva a vida no ócio, importunando as mulheres da aldeia, e nisso não difere do modo de muitos outros jovens indígenas. Esteve presente na aldeia na época do estupro de Célia, mas ficou sabendo do fato no dia seguinte, pelos médicos e pelo pai dela que veio procurá-lo. Antônio tem alguns filhos na aldeia, a maioria fruto desse tipo de ataque sexual e que esse tipo de agressão acontece ali com certa frequência. Ao ser descoberto Antônio fugiu para o mato, aparecendo alguns dias depois. Opina que na aldeia não existe qualquer tipo de tradição com relação ao sexo e que entre os índios não existe senso de justiça ou lei, e que entre eles este fato passará em branco, sem punições.

\section{A ASSISTENTE SOCIAL DA FUNAI}

Nascida no Município de Espírito Santo/PB, solteira, graduada em Assistência Social e residente em Guajará Mirim. Conhece Antônio e soube pelo pai de Célia que ele, Antônio, tem outros filhos na aldeia. Que a revolta do pai de Célia é porque ele tem 21 anos e a sua filha 11. Estava presente no exame de corpo de delito, e o médico disse que Célia não era mais virgem há algum tempo.

Acrescenta que na maioria das aldeias existem problemas de ordem social, pois os pais não cuidam bem dos filhos, permitindo que andem sozinhos a noite e deixando-os muito à vontade, sem que tenham qualquer domínio sobre eles. Acredita que a falta de punição para os índios é incentivo para que outros delitos do mesmo tipo aconteçam .

\section{AGRAVOS À SAÚDE}

"Não há sinais de violência"

\section{INFORME MÉDICO}

O formulário de atendimento de enfermagem registra o seguinte: "hipótese diagnóstica. Paciente vítima de violência sexual? (Tardia). Exame ginecológico sem alterações, ruptura himenal tar- 
dia. Mama, presença de balão mamário. No laudo de exame de corpo de delito consta que não há sinais de violência. Hímen com óstio ovalar apresentando ruptura as 18:00 no sentido horário. Toda ruptura himenal tem mais de 10 dias, para fins de padronização do Instituto Médico Legal. Conclusão: rotura himenal antiga. $\mathrm{O}$ médico do IML declarou que acredita que a vítima tenha tido o hímen rompido antes do ocorrido, embora não possa dar certeza da data. Informa que foi colhido material que possivelmente possa atestar a presença de espermatozoide" (sic).

\section{O PROCURADOR ESTADUAL E O LAUDO ANTROPOLÓGICO}

O Procurador Estadual da República requereu laudo antropológico, baseado na nota técnica de antropóloga que afirma que "toda sociedade tem concepção de dignidade humana e não tolera a sua violação...”. O Procurador entende que a questão seria da alçada da Polícia Civil, por não ameaçar a comunidade, mas tratando-se de criança, envolve os Direitos Humanos e aí cabe à atuação da Polícia Federal. Segue abaixo o teor do seu despacho:

"Esse tipo de conduta, estupro, não condiz com qualquer costume daquela tribo, pretexto comumente alegado, sendo que ["Antônio"] deve arcar com as consequências. $\mathrm{O}$ fato de ser indígena não deve impedir a sua punição. Se porta como qualquer homem branco, possui um grau de aculturação enorme, sendo possível que até rejeite suas próprias tradições. A desordem que impera nos aldeamentos, conforme narrado por servidor da Funai, a fl 33, deve ser combatida pelas autoridades competentes, devendo fazer deste indígena exemplo para os mal-intencionados. Ao que parece, os habitantes daquela aldeia, Rio Negro Ocaia, dizem que nem a PF tem 'moral' para entrar lá dentro".

Conclusão. Indicia Antônio no crime 213, 224 do Código Penal. Remete o processo para o juiz e solicita perícia antropológica. Sete meses depois se registra no processo que o mesmo está parado por falta de perícia antropológica. Volta a solicitar laudo antropológico, visando responder as questões seguintes:

Quais são os aspectos socioculturais que envolvem os fatos, consequências e reflexos. Qual a repercussão para o grupo étnico e parental? Afeta crenças, tradições e costumes? Qual o significado religioso, cultural e social para a etnia e os indivíduos? Há algum elemento inerente a sua cultura que tenha contribuído? A diversidade cultural, crenças, língua e organização social restam afetadas pelos fatos? Outros dados. Na última folha do processo consta ofício que informa que a agenda da antropóloga estará lotada por mais quatro meses.

\section{CENAS-5, 6, 7 E 8 - ENTREVISTAS NA TERRA INDÍGENA.}

\section{MARIA}

Maria tem mais que 60 anos de idade e teve o seu primeiro marido no seringal do governo, em idade púbere, antes de menstruar. Sofreu muita violência física praticada por ele e pelo dono do 
seringal, pois este, em represália à baixa produção, retirou-a do marido (que na ocasião chorou muito por perdê-la), para entregá-la a outro seringueiro. Cita o nome do patrão e diz que ele era muito mau, pois batia nela, explorava seu serviço como cozinheira e exigia sexo; diante de recusa, ele a espancava. Casou pela segunda vez e permanece com o segundo marido de quem também apanhou por muito tempo. Soube que o primeiro marido morreu na cidade, enquanto estava na prisão, por haver assassinado um homem.

Informa em segredo, com muita dor e revolta, que o filho de uma liderança na TI Guaporé, estuprou a sua neta adolescente, acompanhado por dois homens. A moça ficou doente e foi morar TI Rio Negro Ocaia, onde casou com outro rapaz que, infelizmente bate nela e não permite que ela faça as refeições sem a companhia dele (Cena 05). Diz que o estupro acontece muito na TI Rio Negro Ocaia, onde estupraram uma índia (cita o nome) que foi muito espancada, teve a perna quebrada e foi a óbito (Cena 06). Cita que em apenas um dos clãs (informa o nome) Wari, não acontece muito estupro. Maria finaliza me pedindo que ouça a sua filha e outra neta, ambas espancadas pelo marido.

\section{MARCELA}

Marcela, 19 anos, e Bené Wari são casados há quatro anos e têm uma filha de um ano. Ela o considera uma boa pessoa, embora tenham brigas, inclusive de "pancada". Ele está preso em Guajará Mirim acusado de ter estuprado uma moça, em companhia de mais um rapaz (Cena 07). A moça que o acusou, Elisa, 19 anos, mora na mesma aldeia que Bené, é filha de mãe índia e pai "branco", já foi namorada do Bené, e se encontraram em Guajará Mirim, onde ela estuda. Ele foi para lá por alguns dias para fazer um curso para habilitar-se a trabalhar na Usina de Jirau, deixando Marcela na TI Guaporé. A filha deles adoeceu e ela foi para Guajará Mirim, onde recebeu a notícia da prisão de Bené.

Questionado, Bené disse a Marcela que ao ser solicitado por Elisa, levou e buscou a mesma na escola no carro do pai dele e depois foram a uma festa, acompanhados de tio e sobrinho dela. $\mathrm{Na}$ versão dele, ela ofereceu sexo em troca de 25,00 (reais) para comprar abortivo. Fizeram sexo em uma estra$\mathrm{da}$, enquanto o primo dela dormia no carro. Na versão dela, ela pediu dinheiro para comprar um remédio abortivo, mas fez sexo forçada por ele, enquanto foi segurada pelo primo.

Humilhada, mas em nome da filha, Marcela procurou Elisa para convencê-la a retirar a queixa contra os rapazes. Diante da recusa da mesma, bateu nela e a acusou de destruir a família. Elisa disse que pediu dinheiro emprestado a Bené para comprar o abortivo, pois estaria grávida de um "vagabundo", casado e com filhos; além de estar namorando outro rapaz que paga as suas despesas. Não se arrepende da denúncia, pois foi forçada a fazer sexo.

Marcela diz que onde reside não há violência contra a mulher porque são evangélicos. Mas que na Ricardo Franco, o que tem é violência, principal- 
mente contra a mulher. Acredita que a denúncia de Elisa foi motivada por vingança, em decorrência de estupro anterior de parente, que aos 13 anos de idade, foi estuprada por um familiar de Bené, e quase morreu em decorrência (Cena 08). Acredita que houve pedido para Elisa realizar a vingança acusando Bené de estuprá-la.

\section{REFERÊNCIAS}

Albuquerque, A. 2015. Perspectiva bioética intercultural e direitos humanos. Rev. bioética. (Impr.). 23 (1): 80-88.

Alcoreza, R. P. 2012. ¿Cómo interpretar El vivir bien? <http://horizontesnomadas.blogspot.com.br/2012/08/como-interpretar-el-vivir- bien.html>. Acesso em 20 set. 2013

Alcoreza, R. P. 2010. La Fundación de la Segunda República. OSAL, Observatorio social de América Latina, Año XI, no 27, abril. Buenos Aires, CLACSO: 67-72.

Athias, R. 2007. A noção de identidade étnica na antropologia brasileira in De Roquette Pinto à Roberto Cardoso de Oliveira. Recife: UFPe.

Bandeira, L., Almeida, T., M.C de. 2011. Bioética e Feminismo: um diálogo em construção. Revista Bioética (Bioética e Feminismo) 16 (2), Brasília, Conselho Federal de Medicina: 173-189.

Biazzoto, S.R.L de O. 2006. Relatório de Inquérito Policial: gênero e ideologia. Dissertação em Linguistica: UNB.

Boaventura, de S. S. 2009. Direitos Humanos: o desafio da interculturalidade. Revista de Direitos Humanos 2: 10-18.

Cemin, A. B. 2001. Ordem, Xamanismo e Dádiva: o poder do Santo Daime. São Paulo: Terceira Margem.
Cemin, A. B., OTT, A. M. T. 2008. Violência e relações de gênero entre os Wari. Relatório de Pesquisa. Porto Velho, RO, Universidade Federal de Rondônia/Centro de Estudos em Saúde do Índio de Rondônia.

Cemin, A. B. 2011. Educação de populações tradicionais na Amazônia e descolonização do imaginário: qual é a nossa política? in II Colóquio Brasil Alemanha. As ações dos grupos de pesquisa do Brasil e da Alemanha que trabalham com povos e comunidades tradicionais: resultados, práticas e ações futuras. Organizado por A. S. Moret, L. L. C. E. Silva1ed, pp. 89-106. Rio de Janeiro: Letra Capital.

Cemin, A.B. 2011a. Um estudo das violências que afetam as mulheres indigenas: tipos, contextos e estratégias de proteção dentro do respeito à pauta do direito à diferença. Relatório de Pesquisa. Porto Velho/RO: Universidade Federal de Rondônia/UNB,

Cemin, A. B. 2015. Bioética Intercultural Crítica e Antropologia das Civilizações: O "conflito das interpretações" e os Direitos Humanos. XI Reunión de Antropología del Mercosur, 30 de Nov-4 de diciembre, Montevideo, Uruguay.

Clastres, P. 1979. A sociedade contra o Estado. Porto: Afrontamento.

Diniz, D. Bioética e gênero. 2011. Revista Bioética (Bioética e Feminismo) 16(2), Brasília, Conselho Federal de Medicina: 207216.

Diniz, D. e VÈLEZ, A.C. 1999. Bioética feminista: a emergência da diferença. Estudos Feministas 6 (2): 255-64.

Durand, G. 2000. A Imaginação Simbólica. Lisboa: Edições 70

Fassin, D. 2006. La biopolitique n'est pas une politique de la vie. Sociologie et societês 38 (2): $35-48$

Feitosa, S. F; nascimento, W. F do. 2015. A bioética de intervenção no contexto do 
pensamento latino-americano contemporâneo. Revista bioética. (Impr.) 23 (2): 277 84.

Feitosa, S. F. 2015. O Processo de Territorialização Epistemológica da Bioética de Intervenção: por uma prática bioética libertadora. Tese (doutorado), Universidade de Brasília/Programa de Pós-Graduação em Bioética.

Ferreira, C. B. Virando "branca" e subvertendo a ordem? Gênero e transformação no Alto Rio Negro. 2009. Resenha de Lasmar, C. De volta ao Lago de Leite: gênero e transformação no Alto Rio Negro. São Paulo/Rio de Janeiro, Editora UNESP-ISA/NUTI, 2005. Cadernos Pagu 33: 379391.

Fonseca, L. G. D. 2016. Despatriarcalizar e decolonizar o Estado brasileiro - um olhar pelas políticas públicas para mulheres indígenas. Tese (doutorado). Programa de Pós-Graduação em Direito da Universidade de Brasília: Brasília.

Garrafa, V; porto, D. 2003. Intervention bioethics: a proposal for peripheral countries in a context od power and injustice. Bioethics 17(5-6): 399-416.

Garrafa V. 2008. Imperialismo moral - verbete, in: Diccionário latinoamericano de bioética. Editado por Juan Carlos Tealdi. Bogotá: Universidad Nacional de Colombia/Redbioética Unesco, p. 535-536.

Gow, P. 1989. The Perverse Child: desire in a native Amazonian economy. Man 24(4): 567-582.

Lorenzo, CFG. 2011. Desafios para uma bioética clínica interétnica: reflexões a partir da política nacional de saúde indígena. Rev. bioét. (Impr.) 19 (2): 329-42.

Lasmar, C. 2005. De volta ao Lago de Leite: gênero e transformação no Alto Rio Negro. São Paulo/Rio de Janeiro, Editora UNESP-ISA/NUTI.
Lasmar, C. 1999. Mulheres indígenas: representações. Revista Estudos Feministas, ano $7,142,1^{\circ}$ e $2^{\circ}$ semestres.

Lea, V. R. 1999. Desnaturalizando gênero na sociedade M Bengôkre. Revista Estudos Feministas, ano $7,142,1^{\circ}$ e $2^{\circ}$ semestres.

Lea, V.R. 1994. Gênero feminino M ebengokre (Kayapó): desvelando representações desgastadas. Cadernos Pagu 3: 85-116. Campinas: Núcleo de Estudos de Gênero/ Unicamp.

Mccallum, C. 1999. Aquisição de gênero e habilidades produtivas: o caso Kaxinawá. Revista Estudos Feministas, ano 7, 142, $1^{\circ} \mathrm{e}$ $2^{\circ}$ semestres.

Maldi, D. M. 1983. Populações indígenas e a ocupação histórica de Rondônia. Monografia de Especialização em História, Mato Grosso, Universidade Federal do Mato Grosso.

Maus, M. 1974. Ensaio sobre o dom: as formas arcaicas de troca e de contrato. São Paulo, Edusp.

Montero, P. 2006. Índios e Missionários no Brasil, por uma teoria da mediação cultural, in Deus na aldeia: missionários, índios e mediação cultural. Organizado por P. Montero. São Paulo: Globo, p. 31-66.

Nascimento, W.F., Garrafa V. 2011. Por uma Vida não Colonizada - diálogo entre bioética de intervenção e colonialidade. Saúde e Sociedade. São Paulo:, 20 (2):287-299.

Oliveira, R. C. 1994. Antropologia e moralidade. Revista Brasileira de Ciências Sociais 9(24): 110-121.

Quijano, A. 2007. Colonialidad del poder y clasificación social., in El giro decolonial: reflexiones para una diversidad epistémica más alla del capitalismo global. S. Castro-Gómez y R. Grosfoguel, pp. 93 a 126. Bogotá: Siglo del Hombre Editores.

Quijano A. 1992. Colonialidad y moderni- 
dad-racionalidad, in Los Conquistados. Compilado por H. Bonillo, pp. 437-449. Bogotá: Tercer Mundo Ediciones, FLACSO;.

Rodrigues, P. de M. 1999. O surgimento das armas de fogo: alteridade e feminilidade entre os Javaé. Revista Estudos Feministas, ano $7,142,1^{\circ}$ e $2^{\circ}$ semestres.

Sacchi, A. 2009. V Seminário participativo sobre a Lei Maria da Penha. Relatório Preliminar. Porto Velho: FUNAI.

Sacchi, A., Gramkow, M. M. 2012.Introdução, in Gênero e povos indígenas. Coletânea de textos para o "Fazendo Gênero 9" e para a "27". Reunião da Associação Brasileira de Antropologia, ABA". Organizado por A. Sacchi, M. M. Gramko, pp. 15-27. Rio de janeiro; Brasilia: Museu do Índio/GIZ/ FUNAI.

Sales, J. M. 2016. Bioética e violência de gênero nos povos indígenas: diagnóstico de uma negligência. Dissertação em Bioética, Programa de Pós-graduação em Bioética da Universidade de Brasília: Brasília.

Segato, R. L. 2003a. Uma agenda de ações afirmativas para as mulheres indigenas do Brasil. Brasília: Departamento de Antropologia/ UNB, 2003 (Série Antropologia, no 326).

Segato, R. L. 2003b. Las Estructuras Elementales de la Violência. Bernal: Universidad Nacional de Quilmes.

Segato, R. L. 2011. Que cada povo trame os fios de sua historia, CIMI, http://www. cimi.org.br/site/pt-br/?system=news\&act ion $=$ read\&id $=2756$

Segato, R. L. 2011. Género y colonialidad: en busca de claves de lectura y de un vocabulario estratégico descolonial, in $\mathrm{Fe}$ minismos e poscolonialidade: descolonizando el feminismo desde y en América Latina. K. BIDASECA, V. V. LABA. Buenos Aires: Ediciones Godot.

Segato, R. L. 2014. El sexo y la norma: frente estatal, patriarcado, desposesión, colonidad. Revista Estudos Feministas 22(2): 304, maio-agosto. Florianópolis.

Silva, C. T. 2009. Criminalização indígena e abandono legal: aspectos da situação penal dos índios no Brasil, in Problemáticas sociais para sociedades plurais: politicas indigenistas, sociais e de desenvolvimento em perspectiva comparada. C. T. Silva, A. C. S. Lima e S. G. Baines. São Paulo, Annablume; DF, Fundação de Apoio a Pesquisa do Distrito Federal, FAP-DF.

Silva, C. T. da S. 2013. O índio, o pardo e o invisível: Primeiras impressões sobre a criminalização e o aprisionamento de indígenas no Brasil. Antropolitica 34 (1): 137-158. Niterói

Silva, C. T. da S. 2007. Relatório final do projeto Criminalização e Situação Prisional de Índios no Brasil (Edital Projeto de Pesquisa ESMPU no19/2006) http:/ /www.abant. org.br/conteudo/001DOCUMENTOS/ Relatorios/relatorio_final_2007.pdf

Semprine, A. 1999. Multiculturalismo. Bauru/S.P: EDUSC.

Simonian, T. L. 1994. Mulheres Indígenas Vítimas de Violência. XIX Reunião da $A B A$, Niterói, 27-30 de março.

Strathern, M. 2006. O Gênero da dádiva. Problemas com as mulheres e problemas com a sociedade na Melanésia. Campinas, S.P: Editora Unicamp.

Souza, L.D.P de., Cemin, A. B. 2012. Mulheres indígenas em Porto Velho/RO: gênero, migração e participação política, in Gênero e povos indígenas. Coletânea de textos para o "Fazendo Gênero 9" e para a "27ª . Reunião da Associação Brasileira de Antropologia, ABA". Organizado por A. Sacchi, M. M. Gramk, pp. 172-183. Rio de janeiro; Brasília: Museu do Índio/GIZ/ FUNAI.

UNESCO. 2011. Declaração Universal sobre Bioética e Direitos Humanos, Paris, 
2005. Disponível em: http://www.bioetica.catedraunesdoc.unb.br. Acesso em 14 out.

VIAÑA, J. 2010. Reconceptualizando interculturalidad, in Construyendo interculturalidad crítica. La Paz: Andrés Bello, p. 9-61.

Vilaça, A. 1992. Comendo como gente: formas do canibalismo Wari. Rio de Janeiro: UFRJ.

Vitoy, B. 2015. Gênero e mulheres indígenas: um olhar pela Bioética de Intervenção. Dissertação, Programa de Pós-Graduação em Bioética da Universidade de Brasília.

VIVEIROS DE CASTRO, E. 1993. Alguns aspectos da afinidade no dravidiano Amazônico, in Amazônia, etnologia e bistória indígena. Organizado por E. Viveiros de Castro, E. e M. Carneiro da Cunha, pp.149210. São Paulo: NHII/USP.

Walsh, C. 2010. Interculturalidad crítica y educación intercultural, in Construyendo $\mathrm{La}$ interculturalidad crítica. La Paz: Andrés Bello, pp. 96-75.

Woolf, C.S. 1999. Mulheres da Floresta: uma História do Alto Juruá, Acre (1890-1945). São Paulo: HUCITEC.

Recebido em 26/02/2017

Aprovado em 18/03/2017 